\title{
WYKROCZENIA PRZECIWKO PRAWOM PRACOWNIKA - ANALIZA I POSTULATY DE LEGE FERENDA
}

\author{
Abstract \\ Transgression against employees' rights: The analysis and the demands \\ of de lege ferenda
}

In this article the author has made an analysis of the features of particular transgressions comprised in article 281 of the Labour Code, taking into account penal and legal interpretation of the law. The purpose of the analysis was to answer the question if the applied legislative technique is proper and leads to the efficient protection of the essential employees' rights. The analysis allowed to draw conclusions and to formulate some demands towards the legislator. Characterizing the features of the objective side of many transgressions classified in the labor code, taking into account solely linguistic interpretation shall not guarantee the full protection of some employees' rights. In the penal law literature, due to the guarantee requirements, it is assumed that linguistic interpretation, which means explaining the linguistic content of the words and phrases uses in the act based on their meaning that was assigned to them in everyday Polish language, and it is this linguistic interpretation that has the greatest significance in the penal law. The regulations of the law of transgressions cannot be subject to the extended interpretation and an illegal act, according to nullum crimen sine lege rule, stipulated in article 42, paragraph 1 of the Polish Constitution, must have precisely defined characteristics.

Słowa kluczowe: odpowiedzialność karna pracodawcy, pracownik, pracodawca, wykroczenia przeciwko prawom pracownika, wykładnia rozszerzająca

Key words: criminal responsibility of an employer, employee, employer, transgression against employees' rights, extensive interpretation

\section{Wstęp}

Wykroczenia przeciwko prawom pracownika są przede wszystkim skodyfikowane w rozdziale trzynastym Kodeksu pracy zatytułowanym „Odpowiedzialność za wykroczenia przeciwko prawom pracownika”. Przepisy te nie wyczerpują problematyki odpowiedzialności pracodawcy za wykroczenia, gdyż występują jeszcze inne wykroczenia skierowane 
przeciwko prawom pracownika, które zostały stypizowane w innych aktach prawnych. W niniejszym opracowaniu przedmiotem analizy będą jedynie niektóre wykroczenia z art. 281 kp. Rozważania koncentrują się na ochronie prawa pracownika do swobody w wyborze umownej podstawy zatrudnienia, a następnie prawa pracownika do ochrony trwałości nawiązanego już umownego stosunku pracy.

Sankcje karnoadministracyjne są cechą prawa pracy, która odróżnia tę gałąź prawa od prawa cywilnego. Jak wskazuje się w literaturze przedmiotu, tego typu sankcje stanowią zabezpieczenie wykonania obowiązków przez pracodawcę, wzmacniając egzekwowalność praw pracowników ${ }^{1}$. Możliwość zastosowania środków karnych ma istotne, także prewencyjne znaczenie, gdyż staje się czynnikiem skłaniającym do przestrzegania praw pracowniczych, powstrzymując adresatów norm prawnych przed podejmowaniem zachowań naruszających nakazy lub zakazy zawarte w tych normach i motywując ich do podejmowania zachowań zgodnych z normą. Niemniej przepisy zawierające normy prawne muszą być napisane językiem zrozumiałym dla odbiorcy.

W dziedzinie szeroko rozumianego prawa karnego (represyjnego) obejmującego również wykroczenia, gdzie tradycyjnie przyjmuje się, że zakaz albo nakaz obwarowany sankcją karną powinien być sformułowany w sposób precyzyjny i ścisły (zasada nullum delictum sine lege certa), zasada określoności przepisów prawnych nabiera szczególnego znaczenia ${ }^{2}$. Niemniej wiele wykroczeń przeciwko prawom pracownika ustawodawca określa bardzo nieprecyzyjnie.

W art. 281 kp stypizowano osiem rodzajów czynów zabronionych skierowanych przeciwko prawom pracownika. Zachowanie pracodawcy lub osoby działającej w jego imieniu polegające na naruszeniu przepisów prawa pracy może mieć postać działania (np. wypowiedzenie stosunku pracy z rażącym naruszeniem przepisów) bądź zaniechania (np. nieprowadzenie dokumentacji w sprawach związanych ze stosunkiem pracy oraz akt osobowych pracowników). Nie każde zachowanie powodujące naruszenie przepisów prawa pracy wskazane $\mathrm{w}$ art. $281 \mathrm{kp}$ stanowi wykroczenie, musi mieć ono ustawowe znamiona wykroczenia określone w przepisach części ogólnej kodeksu wykroczeń.

\section{Zawarcie umowy cywilnoprawnej w warunkach, w których powinna być zawarta umowa o pracę}

Przede wszystkim ustawodawca w art. 281 pkt 1 kp penalizacją obejmuje zachowanie pracodawcy lub osoby działającej w jego imieniu polegające na zawarciu umowy cywilnoprawnej w warunkach, w których zgodnie $\mathrm{z}$ art. $22 \$ 1 \mathrm{kp}$ powinna być zawarta

\footnotetext{
1 A. Rycak, w: Kodeks pracy. Komentarz, K. Walczak (red.), Lex/el/2016, kom. do 281 kp, teza 1.

2 Por. J. Warylewski, Zasady techniki prawodawczej. Komentarz do rozporządzenia, Warszawa 2003, s. 326, wyrok TK z dnia 28 czerwca 2005 r., sygn. akt. SK 56/04, Legalis, nr 69025, OTK Seria A 2005 r., nr 6, poz. 67.
} 
umowa o pracę. Główny problem wykładni tego przepisu sprowadza się do interpretacji użytego przez ustawodawcę pojęcia „w warunkach” z art. $22 \$ 1 \mathrm{kp}$.

Kodeks pracy nie wprowadza domniemania nawiązania stosunku pracy ani też nie wprowadza zakazu zatrudniania na podstawie umów cywilnoprawnych ${ }^{3}$. Strony same dokonują wyboru stosunku prawnego, na podstawie którego będzie świadczona praca. Kodeksowa zasada wolności (dobrowolności, swobody) nawiązania stosunku pracy, nazywana też zasadą wolności pracy, przejawia się w tym, że do nawiązania stosunku pracy konieczne jest zgodne oświadczenie woli obu zainteresowanych stron tego stosunku prawnego ${ }^{4}$. Jednak w praktyce podnoszone są argumenty, że podmiot zatrudniający wymusza na osobach zatrudnionych zgodę na rezygnację ze statusu pracowniczego, mimo że w istocie praca ma być wykonywana w warunkach charakterystycznych dla stosunku pracy, co jest podyktowane chęcią obniżenia kosztów zatrudnienia i niestosowania przepisów prawa pracy, tylko przepisów Kodeksu cywilnego. Temu zjawisku ma właśnie przeciwdziałać art. 281 pkt $1 \mathrm{kp}$, który ma chronić interes pracownika przy zawarciu umowy o pracę w sytuacji, kiedy powinna być zawarta taka umowa, a nie umowa cywilnoprawna ${ }^{5}$, oraz przepis art. $22 \$ 1^{2} \mathrm{kp}$ mówiący o tym, że nie jest dopuszczalne zastąpienie umowy o pracę umową cywilnoprawną przy zachowaniu warunków wykonywania pracy, określonych w art. $22 \$ 1 \mathrm{kp}$. Nasuwa się więc pytanie, czy w praktyce wspomniane przepisy faktycznie skutecznie ograniczają zjawisko tak zwanego „zatrudnienia śmieciowego” oraz czy adresat normy, organy stosujące prawo i dokonujące „odkodowania” treści regulacji na drodze wykładni normy prawa karnego nie mają wątpliwości, czy określone zachowanie in concreto wypełnia te znamiona, czy nie.

Według ustawodawcy przez nawiązanie stosunku pracy pracownik zobowiązuje się do wykonywania pracy określonego rodzaju na rzecz pracodawcy i pod jego kierownictwem oraz w miejscu i czasie wyznaczonym przez pracodawcę, a pracodawca - do zatrudniania pracownika za wynagrodzeniem. Problem w tym, że niekiedy bardzo trudno dokonać jednoznacznej kwalifikacji, czy praca jest świadczona w ramach stosunku pracy, czy umowy cywilnoprawnej ${ }^{6}$. Tym bardziej że Sąd Najwyższy wskazał, że dopuszczalne jest wykonywanie tych samych obowiązków zarówno w ramach zatrudnienia pracowniczego, jak i cywilnoprawnego, jeżeli nie sprzeciwiają się temu inne okoliczności ${ }^{7}$. Ponadto Sąd Najwyższy w jednym z wyroków ${ }^{8}$ stwierdził również, że praca organizowana przez zatrudniającego, nawet pod jego kierownictwem i kontrolą, świadczona w sposób podporządkowany, nie jest właściwa tylko stosunkowi pracy, stąd wola stron w wyborze podstawy zatrudnienia nie jest bez znaczenia i nie może być

${ }_{3}^{3}$ Wyrok SN z dnia 9 grudnia 1999 r., sygn. akt. I PKN 432/99, Lex.

${ }^{4}$ M. Nałęcz, w: Kodeks pracy. Komentarz, K. Walczak (red.), Legalis/el/2017, kom. do art. 11 kp, teza 1.

${ }^{5}$ M. Bojarski, W. Radecki, Przewodnik po pozakodeksowym prawie wykroczeń, Wrocław 1999, s. 494.

${ }^{6}$ Zob. A. Musiała, Problematyka kwalifikacji umowy o zatrudnienie jako umowy o pracę bądź umowy cywilnoprawnej oświadczenie ustug, Monitor Prawa Pracy 2015, 1, s. 6., Z. Kubot, S. Kowalski, Współczesne problemy zatrudnienia. Wykorzystanie umów śmieciowych dla „ukrycia” stosunku pracy, Warszawa 2016.

7 Wyrok SN z dnia 18 lipca 2012 r., sygn. akt. I UK 90/12, Lex.

8 Wyrok SN z dnia 11 września 2013 r., sygn. akt. II PK 372/12, Legalis. 
pomijana w sporze o kwalifikację zatrudnienia. Natomiast w literaturze prawa pracy od wielu lat podporządkowanie wskazuje się jako szczególną cechę stosunku pracy, która pozwala na przedmiotowe rozróżnienie stosunku pracy od innych stosunków zobowiązaniowych prawa cywilnego"9. Pracownik jest podporządkowany pracodawcy co do zadań, które ma wykonać w ramach umówionego rodzaju pracy, miejsca, czasu i sposobu jej wykonywania. Niemniej w przypadku pracowników wykonujących pracę o wysokich kwalifikacjach (np. główny księgowy) nie występuje, co do zasady, podporządkowanie poleceniom pracodawcy dotyczącym sposobu wykonywania pracy, lecz tylko podporządkowanie zadaniom ${ }^{10}$. W przypadku osób zatrudnionych na stanowiskach kierowniczych i zarządczych pracodawca ma prawo oczekiwać ich aktywności w zakresie sposobu pełnienia pracy, co jednak nie zmienia tego, że pracują one w warunkach podporządkowania $\mathrm{w}$ rozumieniu art. $22 \mathrm{kp}$, gdyż są związane regułami organizacji i funkcjonowania zakładu pracy ${ }^{11}$. Praca świadczona w ramach stosunku pracy jest zawsze odpłatna, ale również za pracę świadczoną w ramach np. umowy zlecenia, co do zasady, należy się wynagrodzenie ${ }^{12}$. Pracownik jest zobowiązany do wykonywania pracy, a więc jego świadczenie ma charakter ciągły i trwa przez z góry określony czas bądź do czasu rozwiązania stosunku pracy w trybie przewidzianym przepisami prawa pracy. Pracownik jest zobowiązany do osobistego świadczenia pracy, co odróżnia stosunek pracy od większości umów cywilnoprawnych, w których możliwe jest wykonanie przedmiotu umowy przez osobę trzecią. Niemniej Sąd Najwyższy stwierdził, że oceny charakteru umowy należy dokonywać nie tylko na podstawie przyjętych przez jej strony postanowień, które mogą mieć na celu stworzenie pozoru innej umowy, lecz przede wszystkim na podstawie faktycznych warunków jej wykonywania. Dlatego też zastrzeżenie $\mathrm{w}$ umowie możliwości zastępowania się $\mathrm{w}$ pracy przez wykonawcę inną osobą nie odbiera jej cech umowy o pracę, zwłaszcza gdy inne cechy badanej umowy wskazują na przewagę cech charakterystycznych dla stosunku pracy ${ }^{13}$.

Zatrudnienie, które posiada cechy określone $\mathrm{w}$ art. $22 \S 1 \mathrm{kp}$, jest zatrudnieniem w ramach stosunku pracy, bez względu na nazwę zawartej przez strony umowy. Sąd Najwyższy podnosi, że jeżeli umowa wykazuje wspólne cechy dla umowy o pracę i umowy cywilnoprawnej o świadczenie usług z jednakowym nasileniem, o jej typie (rodzaju) decyduje wola stron czy też zgodny zamiar stron i cel umowy, który może być wyrażony

9 K. Rączka, Stosunek pracy a cywilnoprawne umowy o świadczenie pracy, Praca i Zabezpieczenie Społeczne 1996, 11, s. 40, A.M. Świątkowski, Kodeks pracy. Komentarz, Legalis/el/ 2016, kom. do art. $281 \mathrm{kp}$, teza 6.

${ }_{10}$ Por. T. Liszcz, Prawo pracy, Warszawa 2016, s. 115; zob. wyrok SN z 7 września 1999 r., sygn. akt. I PKN 277/99.

${ }^{11}$ Postanowienie SN z dnia 11 października 2007 r., sygn. akt. III UK 70/07, Lex.

12 Art. $735 \$ 1$ kc. Jeżeli ani z umowy, ani z okoliczności nie wynika, że przyjmujący zlecenie zobowiązał się wykonać je bez wynagrodzenia, za wykonanie zlecenia należy się wynagrodzenie. $\$ 2$. Jeżeli nie ma obowiązującej taryfy, a nie umówiono się o wysokość wynagrodzenia, należy się wynagrodzenie odpowiadające wykonanej pracy.

${ }_{13}$ Wyrok SA w Krakowie z dnia 16 lipca 2013 r., sygn. akt. III AUa 24/13, Legalis. 
także w nazwie ${ }^{14}$. O charakterze umowy o świadczenie pracy nie może przesądzić tylko jeden jej element, ale całokształt okoliczności faktycznych ${ }^{15}$.

Kolejny problem z wykładnią omawianego wykroczenia dotyczy możliwości ustalenia przez inspektora pracy charakteru stosunku zatrudnienia. W przypadku wystąpienia sporu co do kwalifikacji prawnej zawartej umowy każda ze stron, jak również inspektor pracy (art. 10 ust. 1 pkt. 11 ustawy o Państwowej Inspekcji Pracy, art. $63^{1} \mathrm{kpc}$ ), może, na podstawie art. $189 \mathrm{kpc}$, wystąpić do sądu pracy z powództwem o ustalenie istnienia stosunku pracy. Należy wskazać, że wykroczenie stypizowane w art. 281 pkt 1 kp w znamionach strony przedmiotowej czynu zabronionego nie zawiera przesłanki wcześniejszego sądowego ustalenia istnienia stosunku pracy pomiędzy stronami. Inspektor pracy sam dokonuje ustalenia istnienia lub nieistnienia stosunku pracy, które jest niezbędną przesłanką faktyczną do ukarania sprawcy wykroczenia, czyli czynności zastrzeżonej dla wymiaru sprawiedliwości ${ }^{16}$. Zatem pojawia się pytanie, czy inspektor pracy, zanim ukaże mandatem sprawcę wykroczenia lub skieruje wniosek do sądu o ukaranie obwinionego, może sam dokonać oceny łączącego strony stosunku prawnego. Należy wskazać, że $\mathrm{w}$ literaturze prawa pracy nie wypracowano jednolitego stanowiska w przedmiocie kompetencji inspektora pracy do dokonywania stosownych ustaleń w zakresie charakteru prawnego stosunków zatrudnienia na podstawie art. 281 pkt $1 \mathrm{kp}$. Część przedstawicieli nauki prawa pracy wyraża pogląd, że inspektor pracy w sprawie o wykroczenie nie jest władny samodzielnie ustalić charakteru stosunku zatrudnienia, od którego to ustalenia zależy istnienie wykroczenia ${ }^{17}$. Podnosi się także, że samo przekonanie inspektora pracy o istnieniu stosunku pracy nie powinno być wystarczające do zastosowania kary grzywny wobec pracodawcy, nawet jeżeli przed wystąpieniem z wnioskiem o ukaranie inspektor pracy prowadził czynności wyjaśniające. W tych sprawach wskazuje się, że inspektor pracy powinien korzystać raczej z przysługującego mu szczególnego uprawnienia do wytoczenia powództwa o ustalenie istnienia stosunku pracy w trybie art. $63^{1} \mathrm{kpc}^{18}$. Inni z kolei twierdzą, że inspektor pracy, jako organ orzekający, to znaczy ustalający istnienie przesłanek i decydujący o karze, jest uprawniony do badania konkretnego stanu faktycznego i jest władny ustalić istnienie stosunku pracy. Jednakże autorzy zastrzegają, że ustalenie to nie ma takiej mocy jak wyrok sądowy wydany w procesie o ustalenie stosunku pracy $^{19}$. Prezentowane jest jeszcze stanowisko kompromisowe, w którym autor

${ }^{14}$ Wyrok SN z dnia 18 lipca 2012 r., sygn. akt I UK 90/12, Lex, wyrok SN z dnia 27 maja 2010 r., sygn. akt. II PK 354/09, Lex, Wyrok SN z dnia 18 czerwca 1998 r., sygn. akt. I PKN 191/98, Lex.

${ }_{15}$ Wyrok SN z dnia 7 listopada 2009 r., sygn. akt. III PK 38/09, Lex.

${ }_{16}$ Zob. A. Sobczyk, Metody ograniczania umów cywilnoprawnych w stosunkach pracy - wątpliwości systemowe, Praca i Zabezpieczenie Społeczne 1997, 9, s. 37.

17 T. Liszcz, Prawo pracy, s. 549, 550; S. Płażek, Czy inspektor pracy może samodzielnie kwalifikować umowy?, Praca i Zabezpieczenie Społeczne 1997, 9, s. 38 i n.

18 T. Romer, Prawo pracy. Komentarz, Lex/el/2012, komentarz do art. 281 kp, teza nr 3.

${ }_{19}$ H. Lewandowski, Z. Góral, Przeciwdziałanie stosowaniu umów cywilnoprawnych do zatrudnienia pracowniczego, Praca i Zabezpieczenie Społeczne 1996, 12, s. 32-33. Por. M. Roman, Wykroczenia przeciwko prawom pracownika (art. 281 k.p.), Monitor Prawniczy 2000, 11. 
wskazuje, że uznanie przez państwowego inspektora pracy zawarcia cywilnoprawnej umowy o zatrudnienie za wykroczenie przeciwko prawom pracownika powinno mieć miejsce w przypadkach ewidentnych, niebudzących żadnych wątpliwości. Natomiast w razie wątpliwości pierwszeństwo powinno mieć wystąpienie inspektora do sądu $\mathrm{z}$ roszczeniem o ustalenie istnienia stosunku pracy na podstawie art. $63^{1} \mathrm{kpc}$. Jednak autor zastrzega, że obowiązujące prawo wymagania takiego nie wprowadza ${ }^{20}$.

Tak rozbieżne stanowiska ewidentnie wskazują na potrzebę precyzyjniejszego określenia znamion strony przedmiotowej wykroczenia $\mathrm{z}$ art. $281 \mathrm{pkt} 1 \mathrm{kp}$. Co więcej, penalizacji podlega tylko sam fakt zawarcia umowy cywilnoprawnej, a nie trwanie w takiej umowie. Wykroczenie jest dokonane w momencie, w którym umowa cywilnoprawna została zawarta $^{21}$. W związku z tym występują ograniczenia czasowej możliwości ukarania jego sprawcy z uwagi na okres przedawnienia. De lege ferenda, dodanie do znamion strony przedmiotowej czynu zabronionego przesłanki wcześniejszego sądowego ustalenia istnienia stosunku pracy pomiędzy stronami zapobiegłoby wystąpieniu takich sytuacji, w których może dojść do wydania dwóch rozbieżnych orzeczeń sądów (karnego i pracy) co do charakteru prawnego wiążącego te same strony stosunku prawnego. Ponadto penalizacja trwania w pozornej umowie cywilnoprawnej, a nie tylko sam fakt jej zawarcia, stwarzałaby o wiele większe możliwości ukarania sprawcy tego wykroczenia.

\section{Brak formy pisemnej umowy o pracę}

W doktrynie podnosi się, że zgodnie z zasadą prawa pracy wyrażoną $\mathrm{w}$ art. $11 \mathrm{kp}$ swoboda decydowania o nawiązaniu stosunku pracy obejmuje również wybór podstawy zatrudnienia ${ }^{22}$. Swobodę stron w zakresie wyboru podstawy prawnej zatrudnienia ograniczają niekiedy przepisy prawa pracy, dotyczy to w szczególności możliwości wyboru pozaumownych podstaw zatrudnienia. Ponadto przy powołaniu, wyborze i mianowaniu swoboda pracownika ujawnia się w odmowie wyrażenia zgody na jego jednostronne nawiązanie ${ }^{23}$. W przypadku kiedy do nawiązania stosunku pracy dochodzi na podstawie umowy o pracę, ustawodawca wymaga, aby umowa o pracę była zawarta na piśmie. Jednak forma pisemna nie została zastrzeżona pod rygorem nieważności ${ }^{24}$. W związku z tym zawarcie umowy o pracę w formie ustnej (a nawet w sposób dorozumiany, poprzez

${ }^{20}$ K. Rączka, w: M. Gersdorf, M. Raczkowski, Kodeks pracy. Komentarz, Lex/el/2014, kom. do art. $281 \mathrm{kp}$, teza 2.

${ }_{21}$ W. Radecki, Przestępstwa i wykroczenia przeciwko prawom pracownika, Warszawa 1999, s. 176.

22 B. Wagner, Zasada swobody nawiązania stosunku pracy, Krakowskie Studia Prawnicze 1982, XV, s. 67.

${ }^{23}$ Por. M. Nałęcz, w: Kodeks pracy. Komentarz, K. Walczak (red.), Legalis/2017, kom. do art. 11 kp, teza 5.

${ }^{24}$ Por. wyrok SN z dnia 4 listopada 2009 r., sygn. akt. I PK I 105/09 Lex. 
dopuszczenie do pracy) jest ważne i wiąże strony ${ }^{25}$. Jednakże jeżeli umowa o pracę nie została zawarta na piśmie, ustawodawca nakazuje pracodawcy potwierdzić pracownikowi na piśmie, najpóźniej przed dopuszczeniem go do pracy, ustalenia co do stron umowy, rodzaju umowy oraz jej warunków (art. $29 \$ 2 \mathrm{kp}$ ). Dopuszczenie do pracy w rozumieniu tego przepisu następuje na drodze polecenia pracodawcy podjęcia jej wykonywania przez pracownika $^{26}$.Z kolei potwierdzenie na piśmie nie jest oświadczeniem woli i nie tworzy nowego stanu prawnego. Jest to jedynie oświadczenie wiedzy pracodawcy twierdzącego, że warunki umowy są takie jak w potwierdzeniu ${ }^{27}$. Ustawodawca w art. 281 pkt $2 \mathrm{kp}$ chroni prawo pracownika, który zawarł ustną umowę o pracę, do uzyskania pisemnego potwierdzenia zawarcia takiej umowy przed dopuszczeniem go do pracy.

Należy zauważyć, że literalna wykładnia wykroczenia stypizowanego w art. 281 pkt 2 kp prowadzi do wniosku, że zakres przedmiotowy tego wykroczenia obejmuje tylko zachowanie polegające na niepotwierdzeniu na piśmie zawartej z pracownikiem umowy o pracę przed dopuszczeniem go do pracy lub dokonanie stosownego potwierdzenia na piśmie z naruszeniem terminu na dokonanie tej czynności, a więc po dopuszczeniu pracownika do pracy. W doktrynie i judykaturze przyjmuje się dość powszechnie, że umowa ma tylko jeden element definiujący, jest nim rodzaj pracy ${ }^{28}$. Zatem zakres strony przedmiotowej tego wykroczenia jest węższy niż zakres obowiązku pracodawcy wynikający z art. $29 \$ 2 \mathrm{kp}$. Pracodawca może uchronić się przed odpowiedzialnością już wtedy, jeśli potwierdzi na piśmie co najmniej zawarcie z pracownikiem umowy o pracę ${ }^{29}$. Należy też zauważyć, że nie stanowi wykroczenia niepotwierdzenie na piśmie nawiązania stosunku pracy na innej podstawie niż umowa o pracę.

Niemniej w literaturze prawa pracy prezentowane są także odmienne stanowiska $\mathrm{w}$ kwestii penalizacji zachowania pracodawcy lub osoby działającej w jego imieniu, który potwierdza tylko fakt zawarcia umowy o pracę, a nie potwierdza postanowień dotyczących warunków umowy o pracę, które zostały wskazane w art. $29 \$ 2 \mathrm{kp}$. Według niektórych interpretatorów potwierdzenie zawartej umowy o pracę należy rozumieć jako potwierdzenie nie tylko faktu jej zawarcia, lecz również, a nawet przede wszystkim, warunków tejże umowy, jak na przykład wynagrodzenia, rodzaju pracy, czasu, na który została zawarta, itp. Zdaniem autora wykroczenie wskazane w art. 281 pkt $2 \mathrm{kp}$ jest immanentnie powiązane $\mathrm{z}$ art. $29 \mathrm{kp}$, tym samym naruszenie obowiązku zachowania formy pisemnej, o jakim stanowi właśnie art. $29 \$ 2 \mathrm{kp}$, następuje wtedy, kiedy nie określono warunków umowy o pracę w formie pisemnej ${ }^{30}$.

${ }^{25}$ Por. wyrok SN z dnia 31 marca 1977 r., sygn. akt. I PRN 112/77, Lex, wyrok SN z dnia 5 marca 2015 r., sygn. akt. III PK 50/14, Lex.

${ }^{26}$ K. Jaśkowski, Komentarz aktualizowany do Kodeksu pracy, Lex/el/2017, kom. do art. 29 kp, teza 16.2.

27 Wyrok SN z 25 lutego 2009 r., II PK 176/08, Lex.

${ }^{28}$ J. Stelina, Prawo pracy, Warszawa 2016, s. 144.

29 Por. S. Salwa, Kodeks pracy. Komentarz, Lex/el/2008, kom. do art. 281 kp, teza 3, zob. także A.M. Świątkowski, Kodeks pracy. Komentarz, Legalis/el/2016, kom. do art. 281 kp, teza 9.

${ }^{30}$ D. Książek, w: Kodeks pracy. Komentarz, K.W. Baran (red.), Lex/el/2016, kom. do art. 281 kp, teza 2.2. 
Kolejne wątpliwości przy wykładni znamion przedmiotowych wykroczenia z art. 281 pkt 2 kp wywołuje określenie „na piśmie”, gdyż Kodeks pracy nie precyzuje, co należy rozumieć pod tym pojęciem. Problem z właściwą interpretacją tego wyrażenia uwidocznił się jeszcze bardziej po niedawno wprowadzonych zmianach do Kodeksu cywilnego. W ramach nowelizacji, między innymi, uregulowano w Kodeksie cywilnym definicję dokumentu oraz wprowadzono nową formę czynności prawnych - tak zwaną formę dokumentową ${ }^{31}$. Według nowego art. $77^{2} \mathrm{kc}$ do zachowania dokumentowej formy czynności prawnej wystarcza złożenie oświadczenia woli w postaci dokumentu, w sposób umożliwiający ustalenie osoby składającej oświadczenie, art. $77^{3}$ kc zaś stanowi, że dokumentem jest nośnik informacji umożliwiający zapoznanie się z jej treścią. W związku z wyżej wskazanymi zmianami nasuwa się pytanie, czy znamiona strony przedmiotowej wykroczenia $\mathrm{z}$ art. 281 pkt $2 \mathrm{kp}$ będzie wypełniało zachowanie pracodawcy lub osoby działającej w jego imieniu, jeżeli nie dokona potwierdzenia na piśmie zawarcia umowy o pracę w sposób tradycyjny (czyli kiedy złoży własnoręczny podpis na dokumencie zawierającym określoną treść), tylko sporządzi potwierdzenie zawarcia umowy o pracę, wykorzystując środki komunikacji elektronicznej, które nie będzie opatrzone bezpiecznym podpisem elektronicznym weryfikowanym za pomocą ważnego kwalifikowanego certyfikatu.

Obecnie w Kodeksie pracy, przy dokonywaniu jakiejkolwiek czynności prawnej, ustawodawca nie zastrzega obowiązku zachowania formy dokumentowej ${ }^{32}$. W związku z tym w literaturze prawa pracy sporna jest kwestia, czy umowa o pracę zawarta tylko $\mathrm{w}$ postaci dokumentowej spełnia wymóg pisemności. Utrwalony jest pogląd, zgodnie z którym forma zastrzeżona dla umowy o pracę w art. $29 \$ 2 \mathrm{kp}$ to forma pisemna $\mathrm{z} \mathrm{kc}{ }^{33}$. Podnosi się, że forma dokumentowa może być stosowana wtedy, gdy w Kodeksie pracy nie wprowadzono wymogu formy pisemnej (lub ewentualnie innej) dla danej czynności prawnej, a więc w przypadkach kiedy czynność ta może być dokonana w formie dowolnej ${ }^{34}$. Z kolei według innego stanowiska prezentowanego w doktrynie autorka podnosi, że już obecne przepisy pozwalają na wykładnię, w której elektroniczna postać umowy o pracę

${ }^{31}$ Ustawa nowelizująca z dnia 10 lipca 2015 r., Dz. U., poz. 1311 z późn. zm.

${ }^{32} \mathrm{~W}$ Kodeksie pracy znajdują się zastrzeżenia dotyczące innych form niż pisemna, np. w art. $25^{1}$ $\$ 5 \mathrm{kp}$ („pracodawca zawiadamia właściwego okręgowego inspektora pracy w formie pisemnej lub elektronicznej”), w art. $97 \$ 1^{1} \mathrm{kp}$ („pracodawca jest obowiązany wydać pracownikowi świadectwo pracy wyłącznie na jego wniosek, złożony w postaci papierowej lub elektronicznej”), w art. $129 \S 3$ („rozkład czasu pracy danego pracownika może być sporządzony w formie pisemnej lub elektronicznej”).

${ }^{33}$ Zgodnie $\mathrm{z}$ art. $78 \mathrm{kc}$ do zachowania pisemnej formy czynności prawnej wystarcza złożenie własnoręcznego podpisu na dokumencie obejmującym treść oświadczenia woli. Według obowiązującego od dnia 8 września 2016 r. przepisu art. $78^{1}$ kc, do zachowania elektronicznej formy czynności prawnej wystarcza złożenie oświadczenia woli w postaci elektronicznej i opatrzenie go bezpiecznym podpisem elektronicznym weryfikowanym za pomocą ważnego kwalifikowanego certyfikatu $(\$ 1)$; oświadczenie woli złożone $\mathrm{w}$ formie elektronicznej jest równoważne $\mathrm{z}$ oświadczeniem woli złożonym $\mathrm{w}$ formie pisemnej, chyba że ustawa lub czynność prawna zastrzega inaczej $(\$ 2)$.

${ }^{34}$ K. Jaśkowski, Komentarz aktualizowany do Kodeksu pracy, Lex/el/2017, kom. do art. 29, teza 1.2. 
(bez dochowania wymogów w zakresie bezpiecznego elektronicznego podpisu) będzie spełniała wymóg zastrzeżonej dla umowy o pracę formy „na piśmie”35.

Mając na uwadze występujące $\mathrm{w}$ doktrynie rozbieżności w zakresie wykładni znamion strony przedmiotowej omawianego wykroczenia, de lege ferenda, należy postulować w pierwszej kolejności o precyzyjne powiązanie zachowania pracodawcy lub osoby działającej w jego imieniu z art. $29 \$ 2 \mathrm{kp}$, z którego wynikają dalej idące obowiązki pracodawcy niż tylko potwierdzenie zawarcia umowy o pracę. Ponadto ustawodawca powinien objąć penalizacją także zawarcie w formie ustnej spółdzielczej umowy o pracę, powołania, mianowania, wyboru. Co więcej, zasadny wydaje się postulat o zdefiniowanie wyrażenia „na piśmie” dotyczącego formy potwierdzenia umowy o pracę, jak również samej umowy o pracę.

\section{Ochrona trwałości stosunku pracy nawiązanego na podstawie umowy o pracę}

Ustawodawca oprócz prawa pracownika do swobody w wyborze podstawy zatrudnienia chroni także prawo pracownika do trwałości już nawiązanego stosunku pracy. Dobro to jest przedmiotem ochrony wykroczenia stypizowanego w art. 281 pkt $3 \mathrm{kp}$, przewidującego odpowiedzialność pracodawcy lub osoby działającej w jego imieniu, który narusza przepisy prawa pracy przy wypowiadaniu lub rozwiązywaniu bez wypowiedzenia stosunku pracy w sposób rażący. Wykroczenie ochroną obejmuje wszystkie stosunki pracy, a więc nie tylko nawiązane na podstawie umowy o pracę, ale także nawiązane na podstawie mianowania, powołania, wyboru oraz spółdzielczej umowy o pracę.

Naruszenie przepisów prawa pracy przy wypowiadaniu lub rozwiązywaniu bez wypowiedzenia stosunku pracy można rozpatrywać w dwóch płaszczyznach, mianowicie materialnej oraz proceduralnej ${ }^{36}$. Pierwsza z nich będzie dotyczyć naruszenia przesłanek uprawniających pracodawcę do rozwiązania lub wypowiedzenia umowy (np. naruszenie zakazu wypowiadania stosunku pracy w czasie urlopu pracownika, wypowiedzenie stosunku pracy pracownikowi korzystającemu ze szczególnej ochrony przewidzianej w przepisach prawa pracy), z kolei druga do zachowania procedury wymaganej przepisami prawnymi przy składaniu oświadczenia o rozwiązaniu lub wypowiedzeniu umowy (np. brak przeprowadzenia, wymaganej przepisami prawa konsultacji ze zakładową organizację związkową). Niemniej wszystkie te naruszenia, aby wypełnić znamiona wykroczenia określonego w art. 281 pkt $3 \mathrm{kp}$, muszą być rażące.

Ustawodawca w Kodeksie pracy nie precyzuje, jak należy rozumieć wyrażenie „naruszając w sposób rażący”. W literaturze prawa pracy oraz w judykaturze za rażące naruszenie przepisów prawa pracy uznawane są sytuacje, kiedy bezprawność rozwiązania stosunku pracy jest jaskrawa, oczywista dla każdego, a przez to budząca oburzenie

\footnotetext{
${ }^{35}$ K. Szymorek, Elektroniczna postać umowy o pracę, Monitor Prawa Pracy 2015, 12, s. 637.

${ }^{36}$ M. Roman, Wykroczenia przeciwko...
} 
społeczne $^{37}$. Z kolei T. Nycz ${ }^{38}$ wskazuje, że za rażące naruszenie prawa należy uznać uchybienie przepisom, które cechuje się szczególną nagannością i tym samym narusza istotę, w tym przypadku, instytucji wypowiadania lub rozwiązywania umów bez wypowiedzenia. Według J. Wratnego ${ }^{39}$ rażące naruszenie to takie, które charakteryzuje się wysokim stopniem winy u osoby decydującej o zwolnieniu, jest dla każdego oczywiste i wywołuje dezaprobatę społeczną. Autor jako przykłady wskazuje posłużenie się przez pracodawcę procedurą bezzwłocznego rozwiązania stosunku pracy w sytuacji, kiedy przepisy na zwolnienie pracownika nie zezwalają, albo umyślnie podaje nieprawdziwą przyczynę zwolnienia. M. Nałęcz ${ }^{40}$ uważa, że za rażące z pewnością należałoby uznać naruszenie poważne, widoczne i negatywnie oceniane zarówno przez pracownika, któremu wypowiedziano umowę, jak i przez osoby trzecie.

Zagadnienie „rażącego naruszenia przepisów prawa pracy” w kontekście art. 281 pkt 3 kp było przedmiotem badań przez Trybunał Konstytucyjny w zakresie jego zgodności z przepisami art. 2, art. 30, art. 32, art. 42 ust. 1, art. 45 ust. 1 oraz art. 47 Konstytucji RP. Trybunał Konstytucyjny nie stwierdził niezgodności art. 281 pkt 3 kp z wymienionymi przepisami ustawy zasadniczej. Trybunał wskazuje na istnienie czterech kategorii naruszeń prawa pracy dotyczących zasad rozwiązywania stosunku pracy. Jako pierwsze wymienił świadome (umyślne lub lekkomyślne) naruszenie przepisów wprowadzających w tej mierze określone wymogi materialne (na przykład zwolnienie bezpodstawne albo z naruszeniem zakazu ustawowego). Następnie wskazał na nieświadome (przez niedbalstwo) naruszenie przepisów wprowadzających wymogi materialne. Do trzeciej kategorii zaliczył świadome (umyślne lub lekkomyślne) naruszenie przepisów wprowadzających wyłącznie wymogi formalne (na przykład odnośnie do formy pisemnej, treści wypowiedzenia, konsultacji ze związkami zawodowymi). Jako ostatnią kategorię wymienił nieświadome (przez niedbalstwo) naruszenie przepisów wprowadzających wyłącznie wymogi formalne. Trybunał wskazał, że dominuje stanowisko, wedle którego z naruszeniem przepisów prawa pracy w sposób rażący nie będziemy mieli do czynienia w sytuacjach, kiedy dochodzi do nieświadomego (przez niedbalstwo) naruszenia przepisów wprowadzających wyłącznie wymogi formalne ${ }^{41}$.

Obecnie nie jest możliwe przedstawienie zamkniętego katalogu naruszeń, które miałyby charakter rażący, gdyż dane uchybienie nie jest jednolicie odbierane przez społeczeństwo i nie dla każdego naruszenie jest oczywiste czy jaskrawe, a w wielu sytuacjach za takie powinno być uznane. Ocena rażącego naruszenia musi być obiektywna, a nie subiektywna, dokonana tylko z punktu widzenia pracownika. Niemniej należy podkreślić, że pojęcie „rażące naruszenie przepisów prawa pracy” jest znamieniem ocennym i odnosi się do strony przedmiotowej wykroczenia, a nie strony podmiotowej czy zasady zawinienia.

${ }^{37}$ K.W. Baran (red.), Prawo pracy i ubezpieczeń społecznych, Warszawa 2015, s. 532.

38 T. Nycz, Kodeks pracy z komentarzem, Kraków-Tarnobrzeg 2011, s. 708.

${ }^{39}$ J. Wratny, Kodeks pracy. Komentarz, Legalis/el/2016, kom. do art. 281, teza 2.

${ }^{40}$ M. Nałęcz, w: Kodeks pracy. Komentarz, W. Muszalski (red.), Legalis/el/2015, kom. do art. 281, teza 2.

${ }^{41}$ Wyrok TK z dnia 28 czerwca 2005 r., sygn. akt. SK 56/04, Legalis, nr 69025, OTK Seria A 2005 r., nr 6, poz. 67. 
Ustalenie, czy mamy do czynienia z rażącym naruszeniem przepisów prawa pracy, nie może zatem polegać na ocenie strony podmiotowej czynu ani ustaleniu stopnia winy ${ }^{42}$. Przy analizie konkretnego stanu faktycznego konieczne jest uwzględnienie istotności naruszenia poszczególnych przepisów prawa pracy.

Pierwsza postać wykroczenia stypizowana w art. 281 pkt $3 \mathrm{kp}$ polega na wypowiedzeniu stosunku pracy z rażącym naruszeniem przepisów prawa pracy. Wypowiedzenie jest oświadczeniem woli jednej ze stron stosunku pracy skutkujące rozwiązaniem umowy z końcem okresu wypowiedzenia. Jest to zatem jednostronna czynność prawna, której celem jest ustanie stosunku pracy. Kwestia skuteczności złożonego oświadczenia woli i możliwości jego cofnięcia lub zmiany nie jest uregulowana w Kodeksie pracy. Na mocy jednak art. 300 Kodeksu cywilnego w sprawach nieunormowanych przepisami prawa pracy do stosunku pracy stosuje się odpowiednio przepisy Kodeksu cywilnego, jeżeli nie są one sprzeczne z zasadami prawa pracy. Zgodnie z art. 61 kc oświadczenie woli, które ma być złożone innej osobie, jest złożone z chwilą, gdy doszło do niej w taki sposób, że mogła zapoznać się z jego treścią ${ }^{43}$. Odwołanie takiego oświadczenia jest skuteczne, jeśli doszło jednocześnie z tym oświadczeniem lub wcześniej. Tak więc oświadczenie woli pracodawcy o wypowiedzeniu umowy o pracę jest złożone pracownikowi, gdy doszło do niego w sposób umożliwiający mu zapoznanie się z jego treścią, nie zaś z chwilą przygotowania pisma zawierającego to oświadczenie ${ }^{44}$.

Pracodawca, wypowiadając umowę o pracę na czas nieokreślony, zobowiązany jest wskazać przyczynę, która jest powodem wypowiedzenia. Kodeks pracy nie zawiera katalogu wszystkich przyczyn, które mogą być podstawą zwolnienia pracownika. W judykaturze wypowiedzenie traktowane jest jako zwykły sposób rozwiązania bezterminowego stosunku pracy, a przyczyny je uzasadniające nie muszą mieć szczególnej wagi czy nadzwyczajnej doniosłości ${ }^{45}$. Przyczyna wypowiedzenia powinna zostać sformułowana w sposób konkretny. Wymóg wskazania przez pracodawcę konkretnej przyczyny wypowiedzenia nie oznacza potrzeby sformułowania jej w sposób szczegółowy, drobiazgowy, z powołaniem opisów wszystkich faktów i zdarzeń, dokumentów, ich dat oraz wskazaniem poszczególnych działań czy zaniechań, składających się w ocenie pracodawcy na przyczynę uzasadniającą wypowiedzenie ${ }^{46}$. Sformułowanie jej w sposób ogólny jest dopuszczalne tylko wówczas, gdy okoliczności związane z ustaniem stosunku pracy są znane pracownikowi ${ }^{47}$. W doktrynie prezentowane są różne stanowiska w zakresie objęcia typizacją z art. 281 pkt $3 \mathrm{kp}$ także zachowania polegającego na nieuzasadnionym

${ }^{42}$ A. Rycak, w: Kodeks pracy. Komentarz, K. Walczak (red.), Lex/el/2016, kom. do art. 281 kp, teza 28.

${ }^{43}$ P. Wąż, w: Komentarz do Kodeksu pracy, K. Walczak (red.), Warszawa 2012, s.111.

${ }^{44}$ Wyrok SN z dnia 20 sierpnia 1984 r., sygn. akt. I PRN 111/84, Legalis, nr 24323.

${ }^{45}$ Wyrok SN z dnia 4 grudnia 1997 r., sygn. akt. I PKN 419/97, Lex, nr 33895.

46 R. Sadlik, Wymogi formalne wypowiedzenia zmieniającego, Monitor Prawa Pracy 2013, 10, s. 525, zob. wyrok SN z dnia 25 stycznia 2013 r., sygn. akt. I PK 172/12, Legalis, nr 697884.

${ }^{47}$ Wyrok SN z dnia 4 listopada 2008 r., sygn. akt. II PK 82/08, Legalis, nr 491811. 
wypowiedzeniu umowy na czas nieokreślony ${ }^{48}$. Wydaje się jednak, że znamiona strony przedmiotowej wykroczenia określonego w art. 281 pkt 3 kp nie obejmują zachowania polegającego na nieuzasadnionym wypowiedzeniu umowy o pracę na czas nieokreślony, kiedy podana przyczyna była konkretna, prawdziwa, ale niewystarczająca do skutecznego dokonania wypowiedzenia umowy o pracę na czas nieokreślony. Pracownik ma prawo kwestionować powód zwolnienia, powołując się na okoliczności jego pracy (staż, stosunek do obowiązków pracowniczych, kwalifikacje), wskazując na niezasadność wypowiedzenia. W orzecznictwie utrzymuje się, że podanie prawdziwej przyczyny nieuzasadniającej wypowiedzenie nie narusza art. $30 \$ 4 \mathrm{kp}$, może zaś naruszać art. 45 $\S 1 \mathrm{kp}^{49}$. Niemniej naruszenie w tym wypadku nie powinno zostać uznane za rażące, gdyż trudno ocenić takie zachowanie za działanie, którego bezprawność jest jaskrawa i oczywista, czy naruszające istotę instytucji wypowiadania. Natomiast znamiona strony przedmiotowej wykroczenia z art. 281 pkt $3 \mathrm{kp}$ może wyczerpywać zachowanie polegające na niewskazaniu przyczyny wypowiedzenia umowy o pracę na czas nieokreślony lub podaniu przez pracodawcę przyczyny pozornej (nieprawdziwej) lub niedostatecznie konkretnej, a przez to niezrozumiałej dla pracownika i nieweryfikowalnej. W judykaturze wskazuje się, że w tym wypadku wypowiedzenie umowy o pracę uważane jest za dokonane z naruszeniem prawa, a ściślej - art. $30 \$ 4 \mathrm{kp}^{50}$. Ogólnie można stwierdzić, iż takie zachowanie powinno zostać uznane za rażące naruszenie przepisów prawa pracy, ponieważ jest poważne oraz dotyczy jednej z istotniejszych kwestii wypowiedzenia umowy o pracę na czas nieokreślony.

Kolejny problem z wykładnią znamion strony przedmiotowej wykroczenia z art. 281 pkt 3 kp dotyczy kwestii objęcia penalizacją zachowań pracodawcy lub osoby działającej w jego imieniu polegających na rażącym naruszeniu przepisów prawa pracy przy dokonywaniu wypowiedzenia warunków pracy i płacy. W doktrynie prezentowany jest pogląd, że dla bytu wykroczenia stypizowanego w art. 281 pkt $3 \mathrm{kp}$ istotny jest moment złożenia oświadczenia woli, zatem sięgając do definicji zawartej w art. $30 \$ 1$ pkt $2 \mathrm{kp}$, wypowiedzenie zmieniające jest również wypowiedzeniem w rozumieniu przepisu art. 281 pkt $3 \mathrm{kp}$. W dniu złożenia wypowiedzenia zmieniającego nie można bowiem przewidzieć, do jakiego skutku doprowadzi to oświadczenie woli. W opinii T. Nycza nie ma racjonalnych przesłanek, aby twierdzić, że objęcie normą art. 281 pkt $3 \mathrm{kp}$ wypowiedzenia zmieniającego jest rozszerzającym stosowaniem prawa, gdyż instytucja wypowiedzenia tłumaczona jest na podstawie definicji zawartej w samym Kodeksie pracy, bez potrzeby stosowania rozszerzającej wykładni. Autor ten wyraża pogląd, iż gdyby założyć, że w art. 281 pkt 3 kp ustawodawca nie objął penalizacją wypowiedzenia zmieniającego, to penalizacja tylko wypowiedzenia definitywnego mogłaby nie mieć

${ }_{48}$ Zob. E. Kumor-Jezierska, Z problematyki prawa wykroczeń ochrony stosunku pracy przy przejściu zakładu pracy, Praca i Zabezpieczenie Społeczne 2016, 1, s. 30.

49 Wyrok z dnia 1 kwietnia 2014 r., sygn. akt. I PK 244/13, Legalis, nr 1048600, wyrok z dnia 20 stycznia 2015 r., sygn. akt. I PK 140/14, Legalis, nr 1200463.

${ }^{50}$ Wyrok SN z 10 października 2000 r., sygn. akt. I PKN 641/99, Lex, nr 44878, wyrok z dnia 15 listopada 2006 r., sygn. akt. I PK 112/06, Legalis, nr 175325. 
większego sensu. Ponadto wskazuje, że pracodawca mógłby obejść prawo przez zastosowanie tak skonstruowanego wypowiedzenia zmieniającego, że doprowadziłoby to do ustania stosunku pracy, ponieważ pracownik z reguły takich warunków nie przyjmie ${ }^{51}$.

Instytucja wypowiedzenia warunków pracy lub płacy została wprowadzona do porządku prawnego w celu ochrony trwałości stosunku pracy w sytuacji, gdy pracownik wyraża zgodę na dalsze świadczenie pracy w zmienionych gorszych warunkach pracy ${ }^{52}$. Podobieństwo obu instytucji, wynikające z tego, że z uwagi na treść art. $42 \$ 1$ kp oparte są na podobnym trybie ich stosowania, wydaje się, że nie uzasadnia objęcia zakresem kryminalizacji z art. 281 pkt 3 kp także wypowiedzenia warunków pracy i płacy. W treści art. 281 pkt $3 \mathrm{kp}$ jest jedynie mowa o wypowiedzeniu stosunku pracy, a nie wypowiedzeniu warunków pracy lub płacy ${ }^{53}$. Należy wskazać, że warunkiem prawidłowego dokonania wypowiedzenia zmieniającego "dotychczasowe" warunki zatrudnienia jest zaproponowanie pracownikowi na piśmie nowych warunków zatrudnienia. Wypowiedzenie zmieniające może objąć zarówno warunki pracy i płacy, jak i jeden z tych elementów. W tym trybie można dokonać zmiany tych składników umowy o pracę, które zostały uznane za istotne przez ustawodawcę (składniki przedmiotowo istotne, konieczne) lub strony zobowiązaniowego stosunku pracy (składniki podmiotowo istotne $)^{54}$. Oczywiście zachowanie pracodawcy, polegające na zastosowaniu instytucji wypowiedzenia zmieniającego dla osiągnięcia - poprzez zaoferowanie niemożliwych do przyjęcia przez pracownika nowych warunków pracy i płacy - skutku właściwego dla definitywnego wypowiedzenia umowy o pracę, jest wysoce naganne i może stanowić, jako niepodlegające w myśl art. $8 \mathrm{kp}$ ochronie, nadużycie prawa ${ }^{55}$.

Druga postać wykroczenia określona w art. 281 pkt $3 \mathrm{kp}$ polega na rozwiązaniu stosunku pracy bez wypowiedzenia z rażącym naruszeniem przepisów prawa pracy ${ }^{56}$. Ustawodawca w art. 281 pkt $3 \mathrm{kp}$ nie rozróżnia, czy chodzi o rozwiązanie umowy o pracę bez wypowiedzienia z winy pracownika (art. $52 \mathrm{kp}$ ), czy bez winy pracownika (art. $53 \mathrm{kp}$ ). W myśl zasady lege non distinguente penalizacją objęte są obie podstawy rozwiązania stosunku pracy ${ }^{57}$. Pracodawca może rozwiązać umowę o pracę bez wypowiedzenia $\mathrm{z}$ winy pracownika $\mathrm{w}$ razie: ciężkiego naruszenia przez pracownika podstawowych obowiązków pracowniczych, popełnienia przez pracownika w czasie trwania umowy o pracę przestępstwa, które uniemożliwia dalsze zatrudnianie go na zajmowanym

51 T. Nycz, Kodeks pracy..., s. 709, zob. także Tenże, Wybrane problemy wykroczeń przeciwko prawom osób wykonujących pracę zarobkową, Praca i Zabezpieczenie Społeczne 2000, 3, s. 28.

${ }_{52}$ M. Gersdorf, K. Rączka, Prawo pracy. Podręcznik w pytaniach i odpowiedziach, Warszawa 2013, s. 201.

${ }^{53}$ L. Pawlak, Przestępstwa $i$ wykroczenia przeciwko indywidulanym i zbiorowym prawom pracowników, Warszawa 2010, s. 75.

${ }^{54}$ L. Mitrus, w: Kodeks pracy. Komentarz, A. Sobczyk (red.), Legalis/el/2017, kom. do art. 42, teza 2.

${ }_{55}$ Zob. wyrok SN z dnia 8 marca 2012 r., sygn. akt. III PK 59/11, Lex.

${ }^{56} \mathrm{~W}$ literaturze przedmiotu prawa pracy jest też określane jako wypowiedzenie niezwłoczne lub zwolnienie dyscyplinarne.

${ }^{57}$ R. Celeda, w: Kodeks pracy. Komentarz, L. Florek (red.), Warszawa 2011, s. 1274. 
stanowisku, jeżeli przestępstwo jest oczywiste lub zostało stwierdzone prawomocnym wyrokiem, zawinionej przez pracownika utraty uprawnień koniecznych do wykonywania pracy na zajmowanym stanowisku. Rozwiązanie umowy o pracę bez wypowiedzenia z winy pracownika nie może nastąpić po upływie jednego miesiąca od uzyskania przez pracodawcę wiadomości o okoliczności uzasadniającej rozwiązanie umowy. Pracodawca ma możliwość rozwiązania umowy o pracę bez wypowiedzenia w razie przedłużającej się usprawiedliwionej nieobecności pracownika, po upływie okresów ochronnych określonych w art. $53 \mathrm{kp}$. Do znamion omawianego wykroczenia należy rażące naruszenie przepisów prawa pracy. Pod pojęciem przepisów prawa pracy rozumie się wszystkie przepisy regulujące wymogi formalne, jak również te, które wskazują przyczyny dojścia do niezwłocznego rozwiązania umowy o pracę. W tym wypadku ustawodawca nie rozróżnia nieuzasadnionego rozwiązania stosunku pracy bez wypowiedzenia i niezgodnego z prawem rozwiązania stosunku pracy bez wypowiedzenia ${ }^{58}$. Ten tryb rozwiązania stosunku pracy może znaleźć zastosowanie do rozwiązania przez pracodawcę wszystkich rodzajów umów o pracę, to jest umowy na czas nieokreślony, umowy na czas określony, umowy na okres próbny. Naruszenia przepisów prawa pracy w zakresie rozwiązywania stosunku pracy bez wypowiedzenia przykładowo mogą dotyczyć: braku podstawy materialnej rozwiązania stosunku pracy w tym trybie, zachowania formy pisemnej (art. $30 \$ 3 \mathrm{kp}$ ), wskazania przyczyny rozwiązania (art. $30 \$ 4 \mathrm{kp}$ ), zachowania terminu na rozwiązanie stosunku pracy bez wypowiedzenia (art. $52 \$ 2 \mathrm{i} 3 \mathrm{kp}$ ), uzyskania wymaganej przepisami opinii lub zgody właściwego organu związku zawodowego (art. $52 \S 3$ i $53 \$ 4 \mathrm{kp}$ oraz art. 32 ustawy o związkach zawodowych $)^{59}$. Podobnie jak w przypadku pierwszej postaci wykroczenia również i w tym wypadku wszystkie naruszenia, aby wypełnić znamiona strony przedmiotowej określone w art. 281 pkt 3 kp, muszą być rażące.

Reguła określoności regulacji prawnokarnych nakazuje ustawodawcy takie wskazanie czynu zabronionego (jego znamion), aby zarówno dla adresata normy prawnokarnej, jak i organów stosujących prawo i dokonujących „odkodowania” treści regulacji na drodze wykładni normy prawa karnego nie budziło wątpliwości to, czy określone zachowanie wypełnia te znamiona ${ }^{60}$. Zatem nasuwa się pytanie: Czy wyrażenie „rażące naruszenie" powinno zostać usunięte ze znamion czynu zabronionego? Wydaje się, że wyeliminowanie całkowicie tych słów z art. 281 pkt 3 kp jest nieuzasadnione, w świetle zasady proporcjonalności bowiem nie wszystkie naruszenia przepisów prawa pracy przy wypowiadaniu lub rozwiązywaniu bez wypowiedzenia stosunku pracy zasługują na tak intensywną ochronę. Ponadto ustawodawca powinien również uwzględnić interesy drugiej strony stosunku pracy, czyli pracodawcy. Po dokonanej analizie znamion przedmiotowych wykroczenia stypizowanego w art. 281 pkt $3 \mathrm{kp}$ zasadny wydaje się postulat o objęcie penalizacją nie tylko wypowiedzenia definitywnego, lecz także wypowiedzenia

${ }^{58}$ L. Pawlak, Przestępstwa i wykroczenia..., s. 77.

${ }^{59}$ Wyrok TK z dnia 28 czerwca 2005 r., sygn. akt. SK 56/04, Legalis, nr 69025, OTK Seria A 2005 r., nr 6, poz. 67.

${ }_{60}$ Wyrok TK z 26 listopada 2003 r., SK 22/02, OTK-A 2003, nr 9, poz. 97. 
warunków pracy i płacy dokonanego przez pracodawcę lub osobę działającą w jego imieniu $\mathrm{z}$ rażącym naruszeniem przepisów prawa pracy.

\section{Zakończenie}

Ustawodawca, chcąc zabezpieczyć interesy pracownika jako słabszej strony stosunku pracy, wprowadził do kodeksu pracy katalog wykroczeń. Przepisy prawa wykroczeń nie mogą podlegać wykładni rozszerzającej, a czyn zabroniony, zgodnie z zasadą nullum crimen sine lege wyrażoną w art. 42 ust. 1 Konstytucji RP, musi mieć wyraźnie określone znamiona $^{61}$. W literaturze prawa karnego ze względu na wymagania o charakterze gwarancyjnym wskazuje się, że wykładnia językowa, która polega na wyjaśnieniu treści użytych wyrażeń w ustawie na podstawie znaczenia, jakie nadaje się im w powszechnie używanym języku polskim, ma największe znaczenie w prawie karnym ${ }^{62}$. Niedopuszczalna jest wykładnia rozszerzająca, która przyjmowałaby szerszy zakres penalizacji lub penalizację intensywniejszą, polegająca na ustaleniu znaczenia danego zwrotu czy też zakresu stosowania lub zakresu normowania wykraczającego poza rezultat wykładni językowej63. Przedstawiona w niniejszym opracowaniu wykładnia językowa znamion strony przedmiotowej wykroczeń stypizowanych w art. 281 pkt 1, 2, 3 kp nie sprzyja, co prawda, silnej ochronie praw pracownika, jednak jest właściwa z punktu widzenia funkcji gwarancyjnej prawa karnego.

Wskazane postulaty mają istotne znaczenie, gdyż precyzyjne określenie znamion czynu zabronionego ma kluczowe znaczenie zarówno dla oceny naruszania praw, pracowniczych możliwości pełnego z nich korzystania przez pracownika, jak i dla zapewnienia praworządności w sferze stosunków pracy.

\section{Bibliografia}

Baran K.W. (red.), Kodeks pracy. Komentarz, Lex/el/2016.

Baran K.W. (red.), Prawo pracy i ubezpieczeń społecznych, Warszawa 2015.

Bojarski M., Radecki W., Przewodnik po pozakodeksowym prawie wykroczeń, Wrocław 1999. Florek L. (red.), Kodeks pracy. Komentarz, Warszawa 2011.

Gersdorf M., Raczkowski M., Kodeks pracy. Komentarz, Lex/el/2014.

Gersdorf M., Rączka K., Prawo pracy. Podręcznik w pytaniach i odpowiedziach, Warszawa 2013. Jaśkowski K., Komentarz aktualizowany do Kodeksu pracy, Lex/el/2017.

${ }^{61}$ TK z 13 maja 2008 r., P 50/07, OTK-A 2008, nr 4, poz. 58.

62 Por. V. Konarska-Wrzosek, A. Marek, T. Oczkowski, Podstawy prawa karnego i prawa wykroczeń, Torun 2012, s. 33.

${ }^{63}$ A. Wróbel, A. Zoll, Polskie prawo karne. Częsśc ogólna, Kraków 2014, s. 117. 
Konarska-Wrzosek V., Marek A., Oczkowski T., Podstawy prawa karnego i prawa wykroczeń, Toruń 2012.

Kubot Z., Kowalski S., Współczesne problemy zatrudnienia. Wykorzystanie umów śmieciowych dla „ukrycia” stosunku pracy, Warszawa 2016.

Kumor-Jezierska E., Z problematyki prawa wykroczeń ochrony stosunku pracy przy przejściu zakładu pracy, Praca i Zabezpieczenie Społeczne 2016, 1.

Lewandowski H., Góral Z., Przeciwdziałanie stosowaniu umów cywilnoprawnych do zatrudnienia pracowniczego, Praca i Zabezpieczenie Społeczne 1996, 12.

Liszcz T., Prawo pracy, Warszawa 2016.

Musiała A., Problematyka kwalifikacji umowy o zatrudnienie jako umowy o pracę bądź umowy cywilnoprawnej o świadczenie usług, Monitor Prawa Pracy 2015, 1.

Muszalski W. (red.), Kodeks pracy. Komentarz, Legalis/el/2015.

Nycz T., Kodeks pracy z komentarzem, Kraków-Tarnobrzeg 2011.

Nycz T., Wybrane problemy wykroczeń przeciwko prawom osób wykonujących pracę zarobkowa, Praca i Zabezpieczenie Społeczne 2000, 3.

Pawlak L., Przestępstwa i wykroczenia przeciwko indywidulanym i zbiorowym prawom pracowników, Warszawa 2010.

Płażek S., Czy inspektor pracy może samodzielnie kwalifikować umowy?, Praca i Zabezpieczenie Społeczne 1997, 9.

Radecki W., Przestępstwa i wykroczenia przeciwko prawom pracownika, Warszawa 1999.

Rączka K., Stosunek pracy a cywilnoprawne umowy o świadczenie pracy, Praca i Zabezpieczenie Społeczne 1996, 11.

Roman M., Wykroczenia przeciwko prawom pracownika (art. 281 k.p.), Monitor Prawniczy 2000, 11.

Romer T., Prawo pracy. Komentarz, Lex/el/2012.

Sobczyk A. (red.), Kodeks pracy. Komentarz, Legalis/el/2017.

Sobczyk A., Metody ograniczania umów cywilnoprawnych w stosunkach pracy - wątpliwości systemowe, Praca i Zabezpieczenie Społeczne 1997, 9.

Sadlik R., Wymogi formalne wypowiedzenia zmieniającego, Monitor Prawa Pracy 2013, 10.

Salwa S., Kodeks pracy. Komentarz, Lex/el/2008.

Stelina J., Prawo pracy, Warszawa 2016.

Szymorek K., Elektroniczna postać umowy o prace, Monitor Prawa Pracy 2015, 12.

Świątkowski A.M., Kodeks pracy. Komentarz, Legalis/el/ 2016.

Wagner B., Zasada swobody nawiązania stosunku pracy, Krakowskie Studia Prawnicze 1982, XV.

Walczak K. (red.), Kodeks pracy. Komentarz, Lex/el/2016.

Wróbel A., Zoll A., Polskie prawo karne. Czesść ogólna, Kraków 2014. 